IRA-International Journal of Education \& Multidisciplinary Studies

ISSN 2455-2526; Vol.14, Issue 03 (March, 2019)

Pg. no. 80-83.

Institute of Research Advances

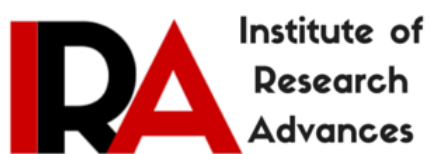

http://research-advances.org/index.php/IJEMS

\title{
On Multimedia-assisted English Vocabulary Teaching for Chinese Junior Middle School English Learners from the Perspective of Situational Teaching Method
}

\author{
CHEN Kai-hua ${ }^{1 \#}$, PAN Cui-qiong ${ }^{2}$ \\ ${ }^{1,2}$ School of Foreign Studies, Yangtze University, Hubei, 434023 PRC China. \\ \#corresponding author. \\ Type of Work: Peer Reviewed \\ DOl: http://dx.doi.org/10.21013/jems.v14.n3.p5
}

\begin{abstract}
How to cite this paper:
CHEN Kai-hua, PAN Cui-qiong. (2019). On Multimedia-assisted English Vocabulary Teaching for Chinese Junior Middle School English Learners from the Perspective of Situational Teaching Method. IRA International Journal of Education and Multidisciplinary Studies (ISSN 2455-2526), 14(3), 80-83.doi: http://dx.doi.org/10.21013/jems.v14.n3.p5
\end{abstract}

(C) Institute of Research Advances.

This work is licensed under a Creative Commons Attribution-Non Commercial 4.0 International License subject to a proper citation to the publication source of the work.

Disclaimer: The scholarly papers as reviewed and published by the Institute of Research Advances (IRA) are the views and opinions of their respective authors and are not the views or opinions of the IRA. The IRA disclaims of any harm or loss caused due to the published content to any party.

Institute of Research Advances is an institutional publisher member of Publishers International Linking Association Inc. (PILA-CrossRef), USA. The institute is an institutional signatory to the Budapest Open Access Initiative, Hungary advocating the open access of scientific and scholarly knowledge. The Institute is a registered content provider under Open Access Initiative Protocol for Metadata Harvesting (OAI-PMH).

The journal is indexed \& included in WorldCat Discovery Service (USA), CrossRef Metadata Search (USA), WorldCat (USA), OCLC (USA), Open J-Gate (India), EZB (Germany) Scilit (Switzerland), Airiti (China), Bielefeld Academic Search Engine (BASE) of Bielefeld University, Germany, PKP Index of Simon Fraser University, Canada. 


\begin{abstract}
The multimedia network technology has been developing so rapidly that a constantly increasing number of course teachings are applying multimedia-based teaching method to fit into the student-centred classroom pattern while improving their teaching efficiency, leading to achievements in the innovation of our education system and offering guidance for EFL teaching and learning. This paper, based on multimedia-assisted teaching, is an attempt at discussing the multimedia-assisted situational English vocabulary teaching by means of the case study, which may prove a more effective method for Chinese junior middle school English learners who are not that skilful in the learning and memorizing of English vocabulary.
\end{abstract}

Keywords: situational teaching method; multimedia-assisted English vocabulary teaching; Chinese junior middle school English Learners

\title{
1. Introduction
}

Since the end of the 20th century, the multimedia network technology has been advancing so fast that multimedia-based teaching method has been widely introduced into a large variety of course teachings for better promotion of efficiency, achievements made in the innovation of our education system and guidance offered for EFL teaching and learning. English vocabulary teaching for junior middle school students is one of these courses which attaches more importance to the very teaching approach in modern education. Vocabulary is acknowledged as the foundation of language learning. Whether a learner can learn it well or not may exert considerable influence on his development of other skills of language learning. Just as Wilkins stated, "Without grammar very little can be conveyed; Without vocabulary, nothing can be conveyed" (1972), which means, "the more vocabulary a learner has, the better understanding he will command in the listening, reading, speaking and writing". Thus, how to teach English vocabulary efficiently to learners is still worthy of our further discussion. This paper, based on multimedia-assisted teaching, as the theoretical framework, attempts to make a case study of the multimedia-assisted situational English vocabulary teaching discussion, which can prove to be a better method for Chinese junior middle school English learners who are not so skilful in vocabulary learning, grasping, memorizing and consolidation.

\section{Some basic concepts}

\subsection{Multimedia-assisted language teaching instructions}

Multimedia-assisted language teaching method involves two kinds of instructions: audio-visual instructions and computer-assisted instructions.

This method indicates that their usage can help teachers and students in creating a certain teaching environment equipped with a mixture of words, objects, audio-video input of image and sounds. Compared with the traditional class with blackboard, picture, object and model, multimedia teaching may activate more interest and bring more benefits to students. Multimedia-assisted language teaching even efficiently combines multimedia teaching with the traditional class. It is no doubt that this method can facilitate the stimulation of learners' motivation in learning and participation in class.

\subsection{Situational teaching method}

Situational teaching method indicates that teachers intentionally create a real-life situation which possesses emotions and images so as to make learners experience emotively in such a way to instruct learners to better understand what they are being taught and fully develop what is weighing in their minds psychologically. The focus of situational teaching method is upon "motivating learners' humanity sentiment in English learning" (Xu Beilian, 2003).

\subsection{Teaching environment established in multimedia-assisted situational teaching classroom}

Multimedia-assisted situational teaching method attempts to establish the teaching environment in which teachers, according to the teaching content, appropriately select the materials from multimedia supplements to create a real-life situation. In this way, two goals can be achieved: 1) to make the teaching content alive in class teaching so that learners can gain the maximal achievement as they are expected, for you see, without the real-life situation, it is hard for Chinese English learners to image how the native English users use English; 2) to foster learners' emotional and attitudinal ability to what they have learnt from the teaching content. In the real-life situation, learners not only learn what the content is about but also experience the culture the content conveys. To achieve the two goals, vocabulary learning must be paid more attention to because "without vocabulary, nothing can be conveyed." (Wilkins, 1972) 


\section{English vocabulary teaching based on multimedia-assisted situational teaching method}

\subsection{English vocabulary teaching}

English vocabulary system includes pronunciation, form and meaning. Learning vocabulary, for the start, must possess the correct pronunciation, then the correct spelling, the word class and lexical collocation, and lastly learners should understand the lexical meaning, grammatical meaning and pragmatic meaning which delineate the difference between the spoken and written language, and tell apart the literal and contextual meaning. To teach vocabulary in class, teachers usually do it in such assisted ways as with the aid of pictures, contexts, actions, media and textbooks which are very similar to the features of multimedia and situational method. This proves that multimedia-assisted situational teaching method is feasible in English vocabulary teaching. Moreover, it can provide more lively input so that it is fit for junior middle school students who are not so mature in English vocabulary learning.

Thus, learning vocabulary well includes two main factors: vocabulary application and retention. The former involves collocation or chunks, idioms, style of words, recognition and reconstruction of words; the latter is a complex process which is related to psychological action. How to attain and maintain a long-term memory of vocabulary proves a real problem to almost all the learners.

The above can be achieved by multimedia-assisted situational vocabulary teaching method as is to be expounded in the following Part 3 with case illustration.

\subsection{Process for English vocabulary teaching in multimedia-assisted situational teaching method}

Based on the communicative approach, the process includes the following sequential steps:

(1) Teachers study the teaching content;

(2) Teachers select proper multimedia aids;

(3) Teachers create proper situational vocabulary teaching;

(4) Teachers provide adequate input of vocabulary;

(5) Teachers create the proper context to ask learners to use the learnt vocabulary;

(6) Teachers create a proper situation to train learners' memory of the learnt vocabulary.

\section{A case study of English vocabulary teaching for junior middle school English learners}

Here is a case study of English vocabulary teaching for junior middle school English learners from the perspective of multimedia-assisted situational teaching:

(1) Teaching contents: Unit $8,1 \mathrm{a}-3 \mathrm{c}$

(2) Teaching time-length: 40 minutes

(3) Teaching procedure:

\section{Teachers study the teaching content.}

The teacher is going to teach students Unit 8 How do you make a banana milk shake? So he must design a teaching plan, which focuses on vocabulary teaching based on the multimedia-assisted situational method.

(2) reachers select proper multimedia aids.

The teacher first asks students to look at the pictures in the book and discuss the new words for today and then usesthe video to introduce the way to make a banana milkshake. The task follows $1 \mathrm{a}, 1 \mathrm{~b}$ and $1 \mathrm{c}$.

(3) eachers create proper situational vocabulary teaching.

The teacher asks students to follow the video, imitate the pronunciation and intonation and understand the grammar and then ask students to do a role-play, aiming at how to describe the process of making banana milkshake. The task follows $1 \mathrm{c}$ in the book again.

\section{4 (4)achers provide adequate input of vocabulary}

The teacher provides more comprehensible new words through a video to students so as to ask students to imitate $2 \mathrm{a}, 2 \mathrm{~b}, 2 \mathrm{c}$ and $2 \mathrm{~d}$ in the book.

\section{(5) reachers create the proper context to ask learners to use the learnt vocabulary.}

The teacher first sums up words in PPT that students must grasp, then asks students to listen to the conversation about $2 \mathrm{c}$ in the book, and finally asks students to do a role play about one act of our daily life on the process of doing something.

\section{(6) Teachers create the proper situation to train learners' memory of the learnt vocabulary;}

The teacher asks students to do group work to summarize today's grammar points and then practice how to use the grammar in our daily life besides the work $3 \mathrm{a}-\mathrm{c}$ in the book. Now play the video again and simultaneously ask students to repeat what the speakers in the video are talking about. Finally, design pair work 
to check students' memory of the learnt vocabulary. Based on the work, the teacher offers the assignments to students, which need students to use the vocabulary learnt today to describe the real-life event.

\section{Analysis of the case study}

Obviously, the teaching procedure well combines the teaching theories with the multimedia-assisted situational method, which fully consists of English vocabulary teaching discipline involving knowing, understanding, using, recognizing and applying. Meanwhile, the class provides a lively and situational atmosphere for learners so as to make the learners more motivated and have a deep thought about what they have learnt.

1. From Step 1, a teaching plan is a very important step which requires the teacher to have a good command of both teaching methodology and multimedia benefits on teaching. It determines whether the class is successful or not. This step must be done before class, which means it is not included in 40 minutes.

2. Step 2 occupying 10 minutes aims at providing new words in the situation of stimulating students' audio-visual sense in order to arouse their interests in learning the new words and make them easily follow the process of making a banana milkshake.

3. In Step 3, the teaching may last 6 minutes. How to correctly read the new words, write the new words and use the new words are attached more importance to, under the help of the video and centered on students.

4. Step 4 shows that more words are presented to students by a video which corresponds with the hypothesis of Krashen's " $i+1$ " (1989). According to the video, students can experience the process of doing something by the sense of listening, watching and speaking. This step can take 6 minutes.

5. In Step 5, the teaching may last 8 minutes and the key learnt words are summarized in PPT which gives students a direct impression and the video about the conversation motivates students' sense of acting and thinking. In this way, word usage is more easily got into their memory.

6. Step 6 occupying 10 plays the watched video again so as to focus on the repetition of what the video shows. On the one hand, students review the learnt before; on the other hand, the memory of new words and new grammar are enforced in the subconscious situation of the video. Then good memory may make students efficiently do their role play. Moreover, higher-level thinking is also involved in acting out the daily life event.

Thus within 40 minutes, how to make a banana milkshake is taught in such a way as to make students easily follow the teacher efficiently. Students may be trained in the 40 minutes from such aspects as listening, watching, reading, speaking, writing, acting, and thinking.

\section{Conclusion}

By virtue of multimedia method, situational vocabulary teaching can help provide a lively situation for junior middle school English learners in building up vocabulary, grasping the new words, understanding and applying them in real life, which is in consistency with the goal of English teaching in our junior middle school education. The multimedia-assisted situational teaching focuses on stimulating the learners' emotional aspect and highly motivates them in language learning, not only in vocabulary development and consolidation but also in grammar study and content-based learning.

Funding: Research for this article was funded by the National Foreign Language Teaching \& Research Projects in Colleges and Universities 2017, P. R. China for "Development of Teaching Skills under the New Normal State of Young Teachers Majoring in Foreign Languages in Colleges and Universities" (Grant No. 2017HB0053A).

\section{References}

[1]. Krashen, S.D. Principle and Practice in Second Language Acquisition[M]. Oxford: Pergamon, 1989.

[2]. Wilkins, David A. Linguistics in Language Teaching[M]. Cambridge: MA: MIT Press, 1972:111.

[3]. Li Chunyan. An Experimental Study on Multimodal Approach to English Vocabulary Teaching in Junior High School[D].Hebei Normal University, 2017.

[4]. Lu Yuesong. An Empirical Study of Situation-based Cooperative Learning in Middle School Oral English Instruction[D]. Hangzhou Normal University, 2017.

[5]. Pan Cuiqiong. Critical Thinking, Critical Thinking Teaching and Its Application[M]. Hubei Education Press, 2012 (5).

[6]. Xu Beilian. A Case Illustration of the Application of Situational Teaching Method in Junior Middle School English Teaching [J]. Journal of Anqiong Teachers College (Social Science Edition), 2003(04): 127-128.

[7]. Zhang Weiyi. A Study on the Effects of Multimedia-assisted Instruction on Junior Middle School Engnlish Vocabulary Learners[D]. Bohai University, 2017. 